\title{
Correction to: The role of epithelial- mesenchymal transition (EMT)-associated genes during gonadogenesis of albino rat
}

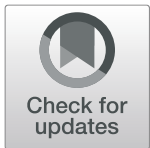

Lina A. Aeshra ${ }^{1}$, Maiada Moustafa ${ }^{2 *}$, Mohammed I. Y. Elmallah $^{3}$, Said Abdelrahman Salih ${ }^{1}$ and Ibrahim Y. Abdel Kader ${ }^{4}$

Correction to: The Journal of Basic and Applied Zoology (2020) 81:2

https://doi.org/10.1186/s41936-019-0137-8

Following publication of the original article (Aeshra et al., 2020), we have been notified that the name of one author was spelled incorrectly as Mohamed Elmallah, when the correct spelling is Mohammed I.Y. Elmallah.

The original article has been corrected.

\footnotetext{
Author details

${ }^{1}$ Chemistry Department, Faculty of Science, Cairo University, Cairo, Egypt. ${ }^{2}$ Zoology and Entomology Department, Faculty of Science, Helwan University, Cairo, Egypt. ${ }^{3}$ Chemistry Department, Faculty of Science, Helwan University, Cairo, Egypt. ${ }^{4}$ British University, Cairo, Egypt.
}

Published online: 03 February 2020

\section{Reference}

Aeshra, L. A., et al. (2020). The role of epithelial-mesenchymal transition (EMT)associated genes during gonadogenesis of albino rat. The Journal of Basic and Applied Zoology, 81, 2 https://doi.org/10.1186/s41936-019-0137-8.

\footnotetext{
* Correspondence: maiadamoustafa11@gmail.com

The original article can be found online at https://doi.org/10.1186/s41936019-0137-8

${ }^{2}$ Zoology and Entomology Department, Faculty of Science, Helwan

University, Cairo, Egypt

Full list of author information is available at the end of the article
} 